Отримано: 13 серпня 2019 р.

Прорецензовано: 15 серпня 2019 р.

Прийнято до друку: 16 серпня 2019 р.

e-mail: nataliazaharevich22@gmail.com

DOI: $10.25264 / 2415-7384-2019-9-52-56$
Nataliia Zakharevych. Key competencies through self-regulated learning, motivation and metacognition in school leavers. Наукові записки Національного університету «Острозька академія». Серія «Психологія» : науковий журнал. Острог : Вид-во НаУОА, серпень 2019. № 9. С. 52-56.

\author{
Nataliia Zakharevych, \\ postgraduate of the National University Ostroh Academy
}

УДК 373.5.041

\title{
KEY COMPETENCIES THROUGH SELF-REGULATED LEARNING, MOTIVATION AND METACOGNITION IN SCHOOL LEAVERS
}

The article ensures a theoretical analysis of the importance of key competencies in self-regulated learning of school leavers in relation to metacognition and motivation. It provides evidence regarding the necessity of self-regulated learning in school leavers. The role of teachers in forming metacognitive skills and motivation is also specified in the article. The importance of using intrinsic motivation instead of extrinsic one in educational process is emphasised.

Key words: key competencies, metacognition, motivation, self-regulated learning, school leavers.

\author{
Захаревич Наталія Василівна, \\ аспірантка Наиіонального університету «Острозька академія»
}

\section{ФОРМУВАННЯ КЛЮЧОВИХ КОМПЕТЕНТНОСТЕЙ ЧЕРЕЗ САМОРЕГУЛЬОВАНЕ НАВЧАННЯ, МОТИВАЦІЮ І МЕТАКОГНЦЦЇ У ВИПУСКНИКІВ ШКІЛ}

\begin{abstract}
У статті подано теоретичний аналіз щодо важливості формування ключових компетентностей у процесі саморегульованого навчання випускників шкіл у взаємозв'язку з метекогніціями і мотивацією. Зазначено очевидність щодо потреби саморегульованого навчання випускників шкіл. Також описано роль учителя у формуванні метакогнітивних навичок і мотивачії. Підкреслено важливість використання у навчальному процесі внутрішньої мотивації замість зовнішньої.
\end{abstract}

Ключові слова: ключові компетентності, метакогніції, мотивація, саморегульоване навчання, випускники щкіл.

Formulation of the problem. School plays an important role in every person's life. It helps to find out things about the environment, to build relationships with everyone in the surrounding, to live and work in our changeable world. The process of education at schools of Ukraine lasts for 9-11 years and after finishing most of the leavers continue their studying at colleges and universities. Everyone who goes to school remembers the years he or she has spent there for the whole life whether they were good or not. So, it is worthy to realize how we can improve our education in order to make it not only obligation in children's lives but also a longterm opportunity based on good knowledge and happy memories about such decisive school years. Moreover, nowadays, the necessity of modern students is not only to acquire and generate knowledge, but also use them actively to succeed in further life. Not the quantity of knowledge but ability of their usage is important today.

Finishing school senior students must know the sustainable ways for living and working and overcome key competencies for lifelong learning. Within this perspective, it seems vital to consider the school as the first important students' steps to the university as a learning and life world.

An analysis of recent researches and publications. Nowadays key competencies are widespread and relevant across different spheres of life and for all individuals, thereby such scientists as Barth M., Godemann J., Rieckmann M., Stoltenberg U., Weinert F., Watson V., and others investigate the role and formation of key competencies in education. The problem of self-regulated learning is highlighted in the scientific studies of Boekearts M., Nilson L. B., Zimmerman B. J., Bolhuis S., \& Voeten M. J. M. etc. The process and structural components of metacognition in education are revealed in the scientific works of Pasichnyk I. D., Kalamazh R. V., Avgustiuk M. M., Livingston J. A., Watson V., Flavell J. H., de Jager B., Jansen M., Reezigt G. and others. The problem of motivation in educational process is researched by Pintrich P. R., Paris S., Winograd P., Dignath C., Buettner G., Langfeldt H. etc.

Nevertheless, there is not enough essential information about the individual development of metacognitive skills and motivation in the process of self-regulated learning forming key competencies in school leavers.

The aim of the study is to analyze the approaches to the studies of psychological mechanisms of metacognitive monitoring and motivation in self-regulated learning of school leavers in the process of key competencies formation theoretically. 
Theoretical background of the problem. The term "competency" is rather popular and discussed not only within the work environment or in the context of educational issues, but has also become a concern in personal and societal everyday life.

However, no agreement exists about what (key) competencies actually are, which are of importance and how the approach of competence acquisition finds its way into higher school education.

Furthermore, the term "key competency" seems of importance as it represents a qualitative extension that points out the special significance of certain competencies. Nevertheless, nowadays, key competencies are relevant across different spheres of life and for all individuals (Rychen and Salganik, 2003).

Thus, UNESCO (2004, p. 20) formulated in its "draft international implementation scheme" about the ESD (education for sustainable development) World Decade:

ESD requires a re-examination of educational policy [.. . ] in order to focus clearly on the development of the knowledge, skills, perspectives and values related to sustainability. This [.. . ] requires a review of recommended and mandated approaches to teaching, learning and assessment so that lifelong learning skills are fostered. These include skills for creative and critical thinking, oral and written communication, collaboration and cooperation, conflict management, decision-making, problem-solving and planning, using appropriate ICTs, and practical citizenship.

Acquiring competencies is hardly comparable with learning as knowledge acquisition. Competencies are described as learnable but not teachable. This leads to the increasing relevance of the question whether and how they may be acquired via learning programmes (Weinert, 2001).

In Ukraine school education is obedient for all children aged 6 to 15 and the role of teacher in the classroom is rather important in acquiring of students' knowledge though, definitely, it has changed significantly over time with developments in the definition of learning. Formerly, learning process was associated with the amount of knowledge and teacher was the most important person in gaining it. Nowadays, it is recognized not only as the active construction of knowledge (de Jager, Jansen \& Reezigt, 2005), but also as the ability to face challenging situations or problems throughout further life. It is evident today that teaching does not automatically lead to learning. The learning activities students engage in largely determine the quality of the learning outcomes they attain (Vermunt, 1999).

This understanding of learning has changed pedagogical approaches to teaching and made it clear for learners to be self-regulated. 'Learning how to learn' has become an important educational issue (Vermunt, 1995) and one of the considerable tasks for teachers to understand how self-regulation can be promoted in the classroom (Williamson, 2015). Besides, it is important for student not only to self-regulate their learning but also to overcome so needed for successful and self-realized life key competencies.

Different researchers paid attention to the problem of teaching and learning in their scientific works. Zimmerman (1990) considered that self-regulated learning focuses primarily on one's ability to think metacognitively, motivationally and behaviourally. Pintrich (1994) viewed learning components as students' knowledge base, their procedural skills, their self-regulation of learning, and their motivation and affect. Zimmerman, Bonner and Kovach (1996) argued that students' self-regulation can be taught and improved through the students' own efforts. However, promoting students' self-regulation is not an easy task because it requires them to spend a lot of time and energy. In addition, promoting self-regulation is only possible when students experience the benefits of self-regulation (Zimmerman, Bonner \& Kovach, 1996).

Higher school education focusing on the development of key competencies needs a reorientation of learning processes and therewith of one of its core tasks. For that purpose a "new learning culture" is necessary, which moves away from a culture of learning based on the principle of indoctrination and is "enabling-oriented, based on self-organisation and centred on competence" (Erpenbeck and Rosenstiel, 2003).

In order to encourage the principle of self-regulation, two different but complementary approaches come to mind: Firstly, a step-by-step opening from very guided to self-regulated learning. This opens the opportunity for gradually testing and applying self-reliance and self-control within the learning process. It also allows less experienced learners a substantial amount of autonomy in the learning process. Secondly, independent project work which is the student's sole responsibility can serve to be a test of self-regulation in a real-life situation.

Consequently, it can be concluded that for successful self-regulated learning, first and foremost competencies or rather personality traits are necessary, which however cannot be directly influenced. They can, nevertheless, form the basis for adapting an individual learning strategy (Barth and Godemann, 2007).

All students are different in their skills and talents, their abilities and approaches, their interests and desires etc. Nevertheless, studying at school every child has the same aim to be successfully socialized (have good relationships with classmates and adults, be confident and popular in some domains, feel support from family and friends, gain success in something and be proud of it) and become a well-realized person in his or her own lives. In this case, it is purposeful to understand individual peculiarities and monitor them in order to succeed in self-regulated learning. 
The close link between metacognition and self-regulated learning is highlighted in scientific works of Zimmerman (1989) and Boekearts (1996). The researchers associates metacognition with the learner's ability to monitor, plan, organize and evaluate their own learning.

Though "the roots" of the concept about metacognition are associated with the name of the developmental psychologist John Flavell. He explained that "metacognition refers to one's knowledge concerning one's own cognitive processes or anything related to them" (Flavell, 1976, p. 232).

We can colligate that metacognition means thinking about thinking and learning.

Various studies approve that better metacognitive skills support higher academic performance of students (Cross \& Paris, 1988). It is clearly, if students understand their individual strong and weak sides and monitor what they know and don't know, think about strategies to learn more effectively, and make predictions about their performance, they are enabled to become more active participants in their self-regulated learning (Paris \& Winograd, 1990) and better overcome necessary key competencies for personal socialization.

Metacognition refers to an individual's awareness and critical analysis of their own thought processes and cognitive ability. The more students are aware of their own comprehension and cognitive processes, the better they are positioned to revise or discontinue them when needed.

The role of metacognition in learning is discussed in works of such researchers as Annemie Desoete and Herbert Roeyers (2001) who singled out various components of metacognition: metacognitive knowledge (deeper understanding of cognitive processes), metacognitive skills (the ability to predict, plan, evaluate and monitor knowledge) and metacognitive beliefs (wide general ideas people have about their own or others' metacognitive processes).

It is evident that "father of metacognition" John Flavell suggested his own model of classification which also consists of three parts: knowledge-of-person (knowing about personal preferences and strengths), knowledgeof-task (understanding the nature of various tasks and what kinds of processing demands they place on the learner), and knowledge-of-strategies (identification and use of various strategies and appropriate times to use them) (Flavell, 1987).

We can conclude, that the proposed, by Flavell, ideas on the development of metacognition as students grow has found their reflection in the learning process. The more students know about themselves and their cognitive processes the better mature learners they become as get older, up until mid high school.

Self-monitoring, in this case, becomes one of the most favorable skills as it enables learners to decide whether their current level of knowledge is enough for gaining their self-set goals (Moos \& Azevedo, 2007). They are able to notice the difference between proper knowledge and steps they ought to do, and choose an appropriate strategy in order to reach their goals. Teachers at school can help their students to overcome metacognitive processes providing their learners with ample opportunity to reflect on their learning, to self-assess in order to self-monitor and evaluate their set goals (Nilson, 2013).

Another important concept connecting key competencies formation and self-regulated learning is motivation.

Motivation is "the key instrument" related to self-regulated learning in schools today. If students are interested and engaged in the material they will never stop in their development in this direction. Many teachers know this peculiarity of the role of motivation in further students' realization and are able to help their fosterlings to succeed in life.

Thereby, though teacher's work requires a lot of preparation to lessons, patience to the students' behavior, especially teenagers' ones, the desire of good teachers is keeping their students motivated and aware of their own cognitive processes during learning experiences. They realize that motivation is the most important "brick in the wall of educational process". Lack of the students' motivation causes difficulties in students comprehention and can lead to poor academic performance.

It is clearly that the years of senior students at high school become "the first steps" in their future lives. Wellmotivated and conscious school leavers understand the importance of further education and do their best to pass the final exams in order to enter the universities they have chosen. Students with lower motivation and without critical analysis of their own cognitive ability study because of their parents who make them, at least, go to school and be present at the lessons.

Accordingly, we can speak about two types of motivation that may influence students learning experience: intrinsic motivation and extrinsic motivation.

Intrinsic motivation refers to internal or personal factors which are specific to each student. Intrinsic motivators can therefore answer questions such as "Why am I studying this subject?" The basis of instrinsic motivation consists of personal reasons of students such as an interest in the subject, a sense of achievement associated with mastery, and an aptitude for the field.

Each student is motivated by personal reasons and different ones, so it is not an easy task for teachers to understand those reasons and learning this information may be a lengthy process during which they build student-teacher relationship. The effects of this process may also take time to manifest in the form of improved 
student performance (Bain, 2004). Intrinsic motivation is influenced by the personal nature of a student, that is why it is often more sustainable than extrinsic motivation.

Extrinsic motivation refers to the external factors that are used to encourage students to participate and perform well in their learning experiences (Bain, 2004). Extrinsic motivators are the external factors that influence student motivation and performance. The basis of extrinsic motivation consists of the expectations of influential individuals (for example, parents, guardians, mentors etc.), the earning potential associated with that field or qualification, and academic performance (grades). Extrinsic motivators answer questions like "What do I get out of this course?" One of the advantages of extrinsic motivation is that it can be quick to result in improved student performance. However, extrinsic motivators may become ineffective over time. Students may require stronger rewards (or punishments) to keep them engaged throughout the learning journey. The removal of rewards or punishments may result in demotivation (Bain, 2004).

In our opinion, motivation is closely connected with emotions. If students are interested in subjects, attend school with pleasure and feel well during the educational process they would like to keep it up. It leads to increasing of their intrinsic motivation. On the contrary, students who often feel badly at school need to be extrinsic motivated to go there. Otherwise, they are able to miss the lessons or, even, don't finish their study and never enter to higher institutions.

We consider emotions connect motivational and metacognitive spheres of people's lives as well. After all self-evaluation as a key component of metacognition is related to emotions. Some students may feel confident in their abilities and be proud of the results they achieve, they may have positive feedback on assignments. All these aspects influence emotional sphere of students and make them highly motivated to attempt new and challenging tasks. Though some students feel frustrated by school and do not attempt new tasks in order not to risk failure. Therefore, the positive or negative emotions affect students' motivation.

Motivation is rather well developed in the primary school students (Snowman, McCowen, \&Biehler, 2009). Evidently, small children are mostly internally motivated to complete the task experiencing something new and interesting for them while motivation of students at the secondary school becomes more external and, without inner interest to the subject, it is rather hard to make them study it. Nevertheless, during all the educational process students with good metacognitive skills show better schooling and use intrinsic motivation in the process of studying.

We can conclude, that high school students with good metacognitive skills realize their strong and weak sides, can monitor and control metacognitive strategies they need to succeed in learning and achieve their best academic results.

As it has been mentioned before, motivation influence metacognition and self-regulated learning although metacognition also affects motivation by helping students to understand their individual struggles in context and offering solutions and techniques to help them improve. Those students who do not achieve much often feel disappointed about schoolwork. Their previous failures influence their self-evaluation and generalize that they are just not smart enough for school. This kind of attitude affects students' motivation. However, all rules have exceptions, and students with good metacognitive skills specify their struggles also identifying areas of strength.

As Paris and Winograd (1990) point out in their article Promoting Metacognition and Motivation of Exceptional Children, "low-achieving students gain self-efficacy as they learn to understand their own frustrations and to understand that others share those feelings too." Therefore, it would be important for students to define their personal strengths and weaknesses through metacognitive exercises during the lessons with teachers' facilitation. It is necessary for students not only understand their own peculiarities but also share their conclusions. Realizing that they are not alone, low-achieving students can observe that every student in the class struggles with some weak sides and has some strong ones. It would also be a real help for students who have generalized specific failures into a global negative affect, specify the domains of their frustration in order to supervise their emotions and find solutions. This is connected directly with motivation. As using metacognition students are able to identify their weaknesses and find strategies to improve them, they can understand better their strong sides, find hope and become motivated.

Students who are highly motivated will tend to have high personal responsibility, willing to take risks, have a plan of study, to be serious, diligent, active in learning, do not feel complacent, always trying to learn the best results (Fuadi, 2009).

Conclusion and prospects for further research. The theoretical rewiew of the literature shows the necessity of developing key competencies for sustainable development of school leavers in higher education. The best way to become successful throughout lifelong learning is self-regulated learning which requires good metacognitive skills and internal motivation. Besides, it is important to apply teaching practices that are most effective in promoting self-regulated learning in order to help the learners develop self-regulatory skills. Teachers and schools should focus on two things simultaneously: 1) teaching the substance of subjects and self-regulation in learning; 2) helping students to develop the competencies and explore values. 
The prospects of the study will be empirical investigation of psychological peculiarities of motivation and metacognitive monitoring in self-regulated learning of school leavers in the process of key competencies formation.

\section{References}

1. Bain, K. (2004). What the Best College Teachers Do. Harvard University Press, Cambridge, MA, 2004.

2. Barth, M., Godemann, J., Rieckmann, M., Stoltenberg, U. (2007), «Developing key competencies for sustainable development in higher education», International Journal of Sustainability in Higher Education, Vol. 8 Iss 4 pp. 416-430.

3. Boekearts, M. (1996). Self-regulated learning at the junction of cognition and motivation. European Psychologist, 1(2), 100-112. doi:10.1027/1016-9040.1.2.100/

4. Bolhuis, S. (2003). Towards process-oriented teaching for selfdirected lifelong learning: A multidimensional perspective. Learning and Instruction, 13(3), 327-347. doi:10.1016/S0959-4752(02)00008-7/

5. Bolhuis, S., \& Voeten, M. J. M. (2001). Toward self-directed learning in secondary schools: What do teachers do? Teaching and Teacher Education, 17(7), 837-855. doi:10.1016/S0742- 051X(01)00034-8/

6. de Jager, B., Jansen, M., \& Reezigt, G. (2005). The development of metacognition in primary school learning environments. School Effectiveness and School Improvement, 16(2), 179-196. doi:10.1080/09243450500114181/

7. Dignath, C., Buettner, G., \& Langfeldt, H. (2008). How canprimary school students learn self-regulated learning strategies most effectively? A meta-analysis on self-regulation training programmes. Educational Research Review, 3(2), 101-129. doi:10.1016/j.edurev.2008.02.00

8. Flavell, J. H. (1987). Speculations about the nature and development of metacognition. In F. E. Wienert \& R. H.

9. Livingston, J. A. (1987). Speculations about the nature and development of metacognition. In F. E. Wienert \&

R. H. Kluwe (Eds.), Metacognition, motivation, and understanding. Hillsdale, NJ: Prentice Hall.

10. Gibbs, R. \& Poskitt, J. (2010). Student Engagement in the Middle Years of Schooling (Years 7-10): A Literature Review. Retrieved from: http://www.educationcounts.govt.nz/_data/assets/pdf_file/0010/74935/940_StudentEngagement-19052010.pdf

11. Linnenbrink, E. (2006). Emotion Research in Education: Theoretical and Methodological Perspectives on the Integration of Affect, Motivation, and Cognition. Educational Psychology Review, 18(4), 307-314.

12. Livingston, J. A. (1997). Metacognition: An Overview. Retrieved from Graduate School of Education: Buffalo, NY website: http://gse.buffalo.edu/fas/shuell/cep564/Metacog.htm

13. Nilson, L. B. (2013). Creating self-regulated learners: Strategies to strengthen students' self-awareness and learning skills. p. 78-85. Sterling, Virginia: Stylus Publishing.

14. Paris, S., \& Winograd, P. (1990). Promoting metacognition and motivation of exceptional children. Remedial and Special Education, 11(6), 7-15.

15. Pintrich, P. R. (1999). The role of motivation in promoting and sustaining self-regulated learning. International Journal of Educational Research, 31(6), 459-470. doi:10.1016/S0883-0355 (99)00015-4

16. Snowman, J., McCown, R., \& Biehler, R. (2009). Psychology Applied to Teaching (12 ed.). Boston: Houghton Mifflin Company.

17. Vermunt, J. D. (1995). Process-oriented instruction in learning and thinking strategies. European Journal of Psychology of Education, 10(4), 325-349.

18. Watson, V. (2008). The Development of Metacognitive Knowledge in Children and Adolescents: Major Trends and Implications for Education. Mind, Brain and Education, 2(3), 114-121.

19. Watson, V. (2004). Principles of effective practice in supporting students to become self-regulated learners. Paper Presented at NZARE Conference, Turning the Kaleidoscope, Wellington, New Zealand. Retrieved from: http:// www.nzcer. org.nz/system/files/14343.pdf.

20. Williamson, G. (2015) Self-regulated learning: an overview of metacognition, motivation and behaviour. Journal of Initial Teacher Inquiry, 1, 25-27.

21. Zimmerman, B. J. (1989). A social cognitive view of selfregulated academic learning. Journal of Educational Psychology, 81(3), 329-339. doi:10.1037/0022-0663.81.3.329.

22. Zimmerman, B.J. (1990). Self-Regulated Learning and Academic Achievement - An Overview. Educational Psychologist, 25(1), 3-17. doi:10.1207/s15326985ep2501_2.

23. Zimmerman, B. J., Bonner, S., \& Kovach, R. (1996). Developing self-regulated learners; Beyond achievement to self-efficacy. Washington, DC: American Psychological Association. 